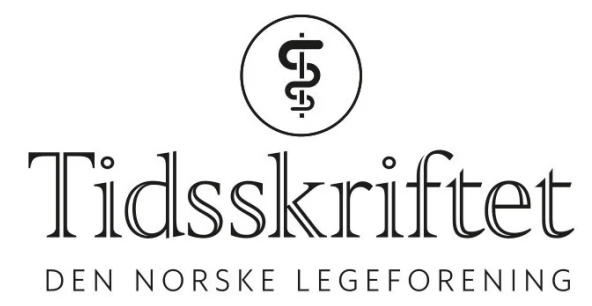

\title{
Håp i et håndtrykk
}

REDAKSJONELL KOMMENTAR

\section{KARI TVEITO}

kari.tveito@tidsskriftet.no

Kari Tveito er medisinsk redaktør i Tidsskriftet. Hun er lege og ph.d.

«Gi barna ti prosent mer håp enn dere har selv», sier legen til Maria og ektemannen. «Men jeg har ikke blitt gitt noe håp», svarer Maria fortvilet. 


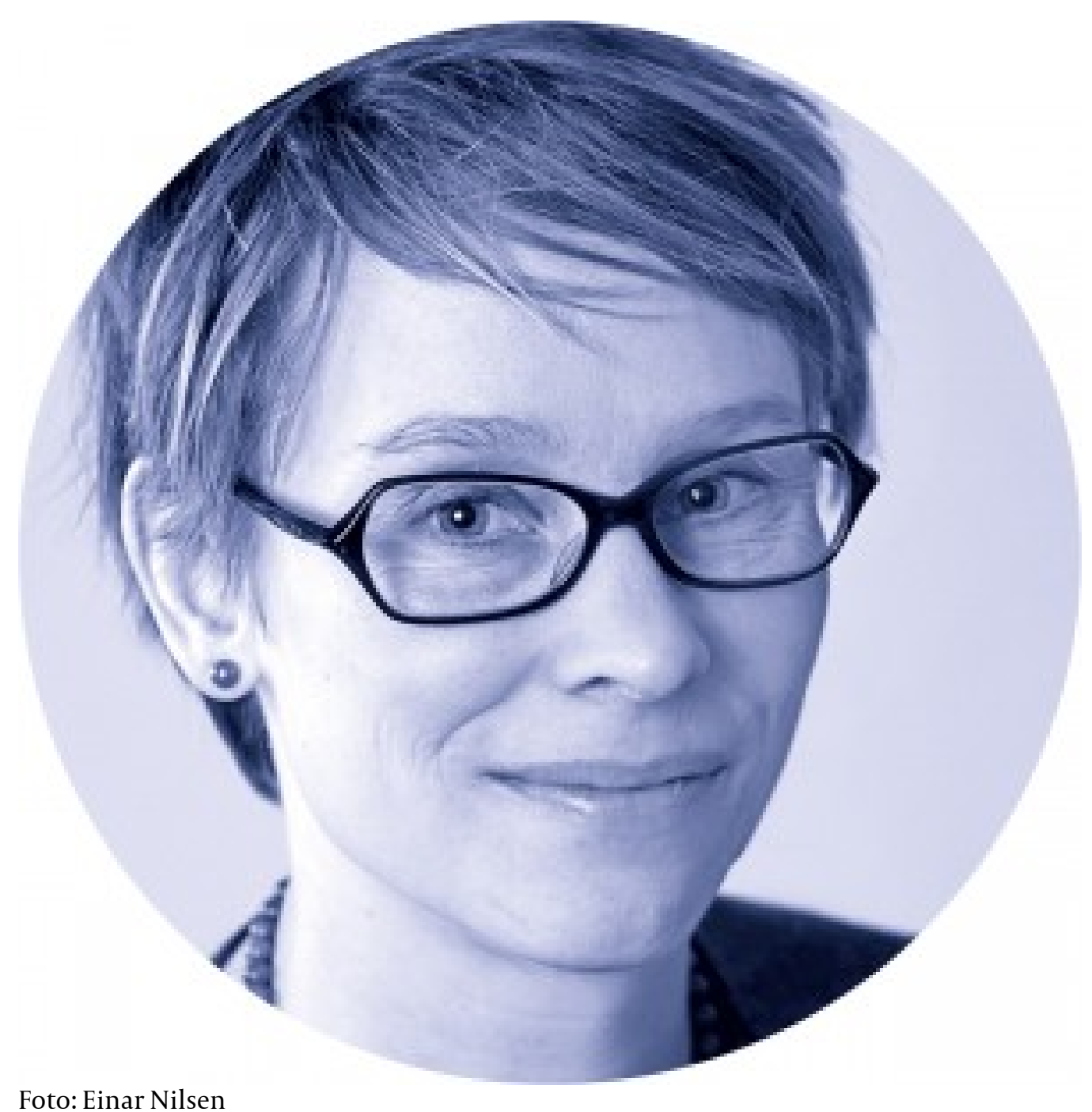

Hva gjør man når livet plutselig blir snudd på hodet? Dette er temaet for filmen Håp, som for tiden vises på norske kinoer (1). Denne moderne julefortellingen er basert på en sann historie. Det var lille julaften da filmregissør Maria Sødahl fikk beskjed om at den intense hodepinen hun hadde kjent en stund, skyldtes en svulst i hjernen.

I filmen spilles Maria av Andrea Bræin Hovig. Hun og ektemannen (Stellan Skarsgård) begynner det som skulle ha vært en fredelig julefeiring, med en desperat søken etter noen som kan gi svar på alle spørsmålene: Kan noe gjøres? Vil hun overleve? Hva skal de si til barna som er hjemme og gleder seg til å feire jul?

Igjen og igjen reiser de til sykehuset denne romjulen. Men herberget for de syke og trengende er fullt. Det er ferieavvikling og sykepleieren som er «ekspert på å snakke med pasienter», er ikke der. Callingen piper, og før de vet ordet av det, har legen de treffer i mottaket, gått sin vei - for Maria har jo allerede fått både sovetabletter og beroligende medisiner.

Letingen etter noen som kan lytte, forstå og kanskje gi noen råd, ender på Lovisenberg Lindring og Livshjelp i Oslo (tidligere Hospice Lovisenberg). Idet paret trer inn på senteret, der det er fyr på peisen og alt er stille og fredelig, senker roen seg. I et lite rom med små vinduer og en dyp sofa finner endelig en forløsende samtale sted.

Kanskje er det ikke tilfeldig at det er Bente Westad, kreftsykepleieren som hjalp filmregissøren i virkeligheten, og som spiller seg selv i filmen, som finner tid og rom (2). Møtene med leger - som også spilles av virkelige leger i filmen - finner gjerne sted $\mathrm{i}$ korridorer, kantiner, mottak eller venterom. For som en av legene forteller ekteparet, «vil det ta for lang tid å gå til kontoret». 
Kravene til leger, sykepleiere og andre helsearbeidere på sykehus, legevakter og fastlegekontorer kan noen ganger føles umulige. Det blir ikke tid til å sette seg ned med hver enkelt pasient og gi dem all den oppmerksomheten de kanskje trenger. For mye venter, køen er for lang, behovene til så mange mennesker med til dels livstruende tilstander må prioriteres. Bedre blir det ikke i høytider og ferier. Men filmen Håp minner oss likevel om noe viktig: Det å virkelig komme et annet menneske i møte er noen ganger det som betyr mest. Noen få ord, en klem eller et håndtrykk kan være det som gir styrke til å gå videre, selv når man ikke tror man kan klare mer. En av de unge legene i Håp blir så glad på pasientens vegne da CT-bildene ikke viser tegn til spredning i lungene, at hun ikke klarer å vente med å gi denne beskjeden. Idet Maria kommer til mottakelsen, står legen i døra med det glade budskap. Og når Maria, overveldet av lettelse, bryter sammen, er legen der og holder henne i hånda.

En hånd som holder en annen hånd, et menneske som møter et annet menneske. Heri ligger kanskje noe av livets mening. Dikteren Arnold Eidslott uttrykte det slik (3):

Gå sakte og let

etter de rådløse hender

Hvert håndtrykk føder en stjerne

\section{LITTERATUR}

1. Sødahl M. Håp. Film. Oslo: Produksjonsselskap Motlys AS, 2019.

2. Bergsagel I. Kreftsykepleier Bente Westad spiller seg selv i ny kinofilm. Sykepleien.no 20.11.2019. https://sykepleien.no/2019/11/kreftsykepleier-bente-westad-spiller-seg-selv-i-ny-kinofilm Lest 18.12.2019.

3. Eidslott A. Håndtrykket. Adam imago Dei. Diktsamling. Oslo: Gyldendal Norsk Forlag, 1984.

Publisert: 19. desember 2019. Tidsskr Nor Legeforen. DOI: 10.4045/tidsskr.19.0823

(C) Tidsskrift for Den norske legeforening 2023. Lastet ned fra tidsskriftet.no 26. april 2023. 